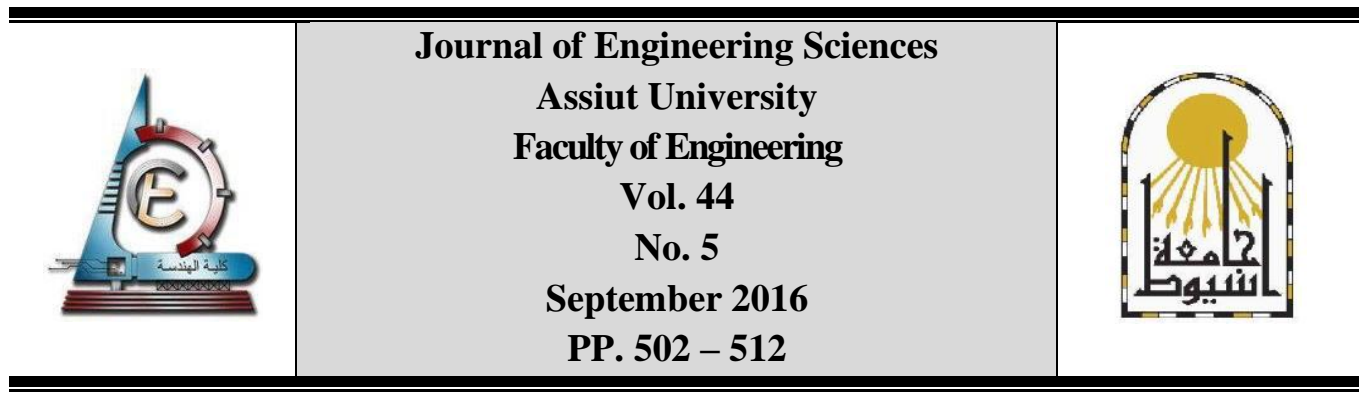

\title{
EFFECT OF USING HIGHLY CONFINED SHORT LAP-SPLICE REINFORCEMENT ON SEISMIC PERFORMANCE OF EXTERIOR BEAM-COLUMN JOINT
}

\author{
Girgis F.G. Sharobeem ${ }^{1}$, Mohamed F. M. FAhmy ${ }^{2}$, Omar A. Farghal ${ }^{3}$ \\ ${ }^{I}$ Master student, Department of Civil Engineering Faculty Assiut University, and Engineer at \\ the General Authority for Educational Buildings in Sohag \\ ${ }^{2,3}$ Department of Civil Engineering, Faculty of Engineering, Assiut University
}

Received 16 June 2016; Accepted 24 July 2016

\begin{abstract}
The present paper aims to examine the behavior of exterior beam-column joints with different reinforcement details of their columns: continuous and lap splice longitudinal bars were adopted as design parameter. The experimental program was carried out at the Concrete Research Laboratory at Housing and Building Research Center in Egypt; included three exterior reinforced beam column joints that were tested under the effect of quasi-static cyclic loading. One sample was designed according to the provisions of the current seismic design codes and served as a control sample. Columns of the other two samples were detailed with well confined shorter lap spliced longitudinal reinforcement. The overall behavior of the beam-column joints and conclusions are discussed in this paper.
\end{abstract}

Key words: Lap-splice, beam-column, confined, exterior joint, seismic.

\section{Introduction}

The lap splice in the reinforced concrete columns in the old buildings was usually designed as compression lap splice, usually from 20 to 24 times of bar column main steel reinforcement, and just above slab and not confine properly.

Since 1970, many researchers studied the behavior of columns with lap splice like: Aboutah et al. [1] tested specimens had a splice length of $20 d_{p}$ and detailed according to the provisions of ACI318-63.The test results revealed that the reference samples with short lap splice exposed to the collapse because of poor of bond before reached to their capacity moments at the critical section

Lynnet et al. [2], He studied eight samples to study the behavior of the columns, of which three samples were lap splice length between 20 to 25 times of bar column main steel reinforcement and located at base of column, he observed that all sample failed in shear.

* Corresponding author.

Email address: girgis_f@yahoo.com 


\section{Research objectives}

Study effect of column longitudinal reinforcement details, e.g. continuation or lap-splice details of steel bars above the column-beam joint, affect the performance of a well detailed beam-column joint? This study was selected length of lap splice $20 d_{p}$ times as pervious researchers [1] and [2] and also $15 d_{p}$ to study the behavior changes within comparability, but both samples well conferment by transverse reinforcement as the code requirements.

\section{Experimental program}

The test was carried out at the Concrete Research Laboratory at Housing and Building Research Center in Egypt. Three 2/3 scale exterior reinforced beam-column joints were tested under quasi-static displacement control technique. In all specimens the column was loaded by constant compressive axial load, while the free end of the beam was subjected to cyclic load in order to simulate the case of Seismic action [3].

Order to naming the specimens, $\mathrm{R}-\mathrm{CO}$ was used to describe the control sample (continuous steel reinforcement), R-SP15 was used to describe the second sample (lap splice length is 15 $d_{p}$ ) and R-SP20 was used to describe the thread sample (lap splice length is $20 d_{p}$ )

\subsection{Test specimens}

All specimens were designed according to concept of strong column - weak beam, the section capacities are designed to have the ratio $\sum M_{c} / \sum M_{b}$ of 1.2 for all specimens, they have identical concrete dimensions, the column had a rectangular cross section of $300 \mathrm{~mm}$ depth, $200 \mathrm{~mm}$ width and $2000 \mathrm{~mm}$ clear height while the beam have a rectangular cross section of $400 \mathrm{~mm}$ depth and $200 \mathrm{~mm}$ width and $1500 \mathrm{~mm}$ clear span from column face. The first specimen R-CO is the control joint of ribbed steel and the followed two specimens (R-SP15, R-SP20) were detailed with $15 d_{b}$ and $20 d_{b}$ lap-splice and wellconfined by transverse reinforcement. The dimensions and reinforcement details of test specimens are shown in Fig.1 and Table 2.

\subsection{Material properties}

The concrete mixes used to cast the specimens were developed through trial batching using the absolute volume method. The mixes were designed to develop standard cubic strengths of $30 \mathrm{~N} / \mathrm{mm}^{2}$.the concrete mix consisted of fine aggregate, coarse aggregate, cement, water. A concrete test cube was cast for mix to determine its mechanical properties at same time as the beam-column joint. Quantities of materials required for $1 \mathrm{~m}^{3}$ was (712 $\mathrm{kg}$ fine aggregate, $1081 \mathrm{~kg}$ coarse aggregate, $350 \mathrm{~kg}$ cement and 192.5 liter water). High strength steel-deformed types of 10,12mm diameter and steel-smooth type $6 \mathrm{~mm}$ were used in specimens' reinforcement properties shown in Table 1.

Table 1.

Properties of steel bars reinforcement.

\begin{tabular}{|c|c|c|c|c|}
\hline $\begin{array}{c}\text { Diameter } \\
(\mathrm{mm})\end{array}$ & Grade & $\begin{array}{c}\text { Yield Strength } \\
\left(\mathrm{N} / \mathrm{mm}^{2}\right)\end{array}$ & $\begin{array}{c}\text { Max. Strength } \\
\left(\mathrm{N} / \mathrm{mm}^{2}\right)\end{array}$ & $\begin{array}{c}\text { Ultimate Strength } \\
\left(\mathrm{N} / \mathrm{mm}^{2}\right)\end{array}$ \\
\hline 6 & $24 / 35$ & 335.1 & 531.1 & 379.3 \\
\hline 10 & $36 / 52$ & 578.1 & 678.3 & 541.8 \\
\hline 12 & $36 / 52$ & 509.0 & 644.9 & 565.9 \\
\hline
\end{tabular}




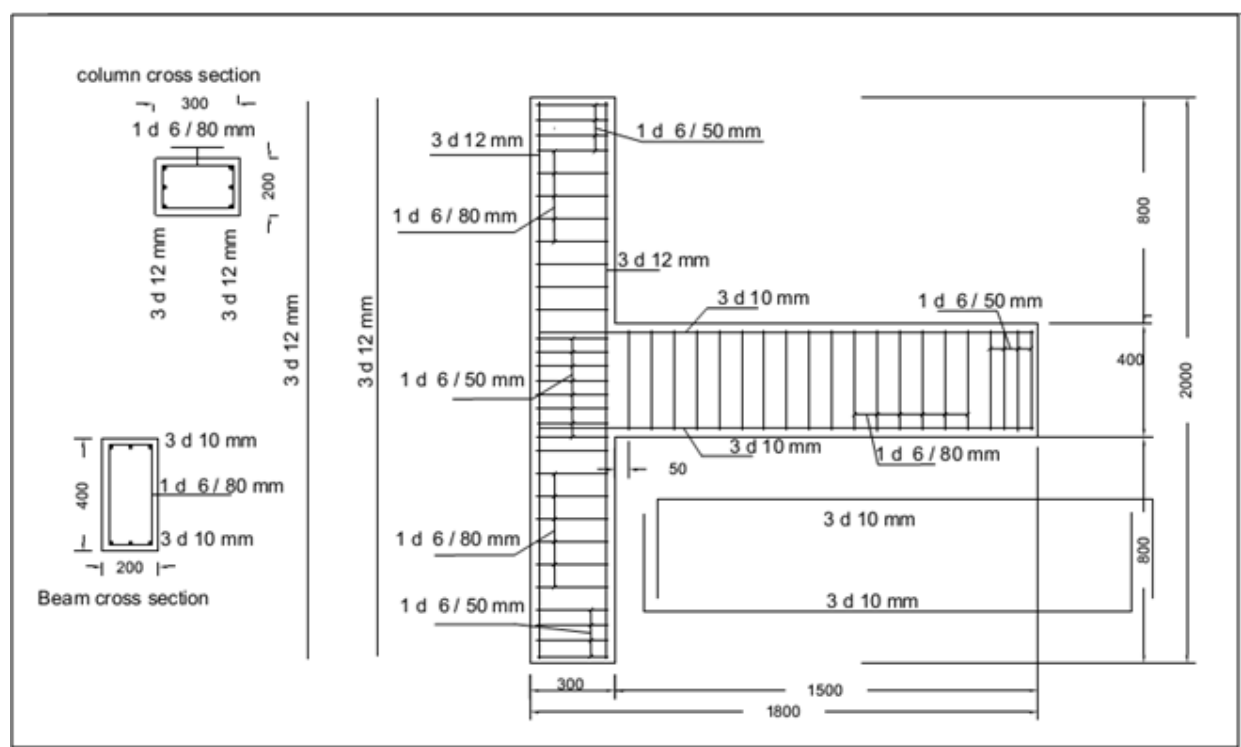

a) specimen $\mathrm{R}-\mathrm{CO}$

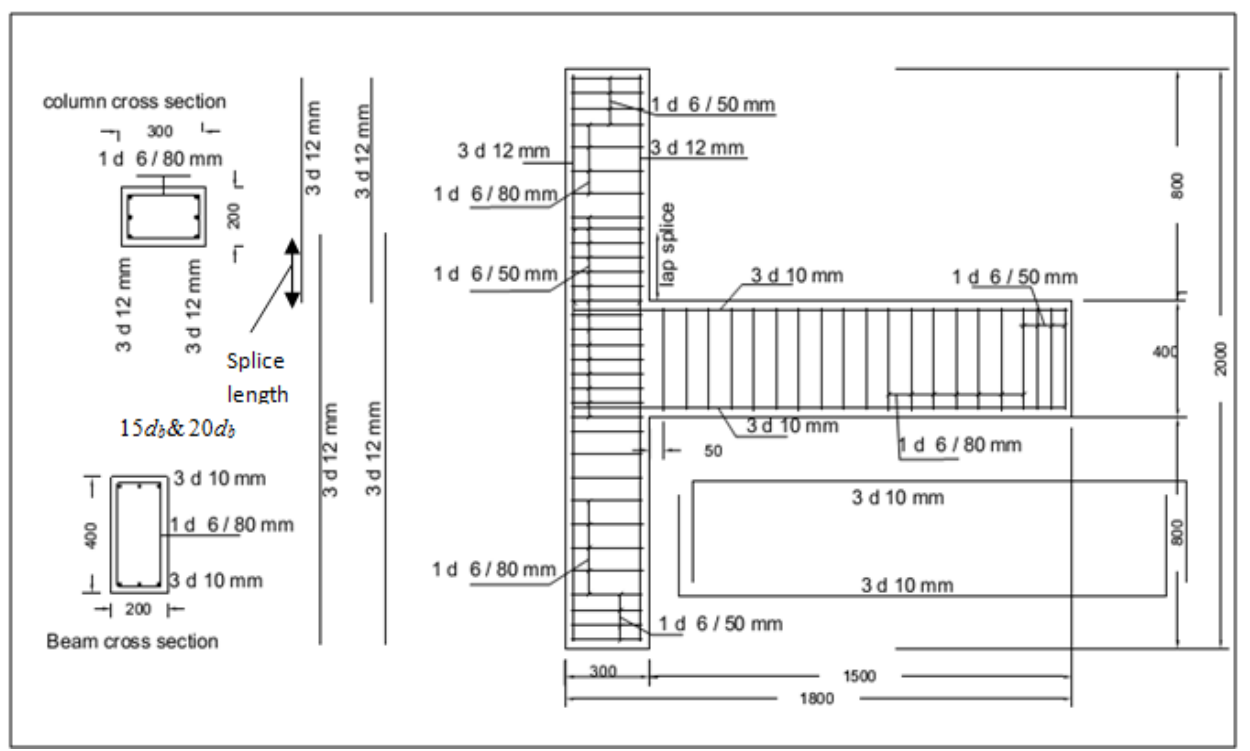

b) Specimens R-SP15 \& R-SP20

\subsection{Test set - up}

Fig. 1. Reinforcement details for test Specimens.

Figure 2 shows the steel frame where samples were tested at the Concrete Research Laboratory at Housing and Building Research Center in Egypt also shows the devices, which used to take readings. Types of instruments were used; load cell to measure the applied beam and column loads., A LVDT was attached to the bottom face of the beam at a point $250 \mathrm{~mm}$ away from the beam end, parallel to the direction of the applied cyclic load, to obtain the beam tip displacement, Electrical strain gages were used to measure the steel strains of the top longitudinal reinforcement of the beam. 
Girgis F.G. Sharobeem et al., Effect of using highly confined short lap-splice reinforcement on .......

Table 2.

Samples reinforcement details.

\begin{tabular}{|c|c|c|c|c|c|c|c|c|c|}
\hline \multirow{4}{*}{ Specimen } & \multicolumn{3}{|c|}{ Beam } & \multicolumn{4}{|c|}{ Column } & \multirow{2}{*}{\multicolumn{2}{|c|}{$\begin{array}{c}\text { Joint } \\
\text { Transverse R ft. }\end{array}$}} \\
\hline & $\begin{array}{l}\text { Long. } \\
\mathrm{R} f t .\end{array}$ & \multicolumn{2}{|c|}{$\begin{array}{c}\text { Transverse R } \\
\text { ft. }\end{array}$} & $\begin{array}{l}\text { Long. } \\
\mathrm{R} \mathrm{ft.}\end{array}$ & \multicolumn{2}{|c|}{ Transverse R ft. } & \multirow{3}{*}{$\begin{array}{l}\text { Lap } \\
\text { splice }\end{array}$} & & \\
\hline & \multirow[t]{2}{*}{ As } & $\begin{array}{l}\text { Bar } \\
\text { size }\end{array}$ & Space & \multirow[t]{2}{*}{ Bars } & $\begin{array}{l}\text { Bar } \\
\text { size }\end{array}$ & Space & & $\begin{array}{l}\text { Bar } \\
\text { size }\end{array}$ & Space \\
\hline & & $(\mathrm{mm})$ & $(\mathrm{mm})$ & & $(\mathrm{mm})$ & $(\mathrm{mm})$ & & $(\mathrm{mm})$ & $(\mathrm{mm})$ \\
\hline $\mathrm{R}-\mathrm{CO}$ & $\begin{array}{c}3 \# 10 \\
+ \\
3 \# 10\end{array}$ & 6 & 80 & $\begin{array}{c}3 \# 12 \\
+ \\
3 \# 12\end{array}$ & 6 & 80 & 一 & 6 & 50 \\
\hline R-SP15 & $\begin{array}{c}3 \# 10 \\
+ \\
3 \# 10\end{array}$ & 6 & 80 & $\begin{array}{c}3 \# 12 \\
+ \\
3 \# 12\end{array}$ & 6 & 80 & $15 d$ & 6 & 50 \\
\hline R-SP20 & $\begin{array}{c}3 \# 10 \\
+ \\
3 \# 10\end{array}$ & 6 & 80 & $\begin{array}{c}3 \# 12 \\
+ \\
3 \# 12\end{array}$ & 6 & 80 & $20 \mathrm{~d}$ & 6 & 50 \\
\hline
\end{tabular}

\subsection{Test procedure}

The samples were tested under quasi-static displacement control technique. The cyclic load was applied at the tip of beam test joints. while the column loaded by constant axial load was $0.15 \mathrm{fc}^{\prime} \mathrm{Ag}$.The control sample (R-CO) was loaded by cyclic load with corresponding to displacement $1.5 \mathrm{~mm}$ at cycles from 1 to 3 and $3 \mathrm{~mm}$ displacement at cycles 4 to 5 in order to determine the value of yield displacement which occurred at sixth cycle with $6.14 \mathrm{~mm}$ as shown in Fig 3.

After determining yield displacement for the control joint the test was continued by loading the specimen by loads equal to multiples of the recorded yielding displacement up to failure. In this way the rest of the samples tested after knowing the value of yielding displacement
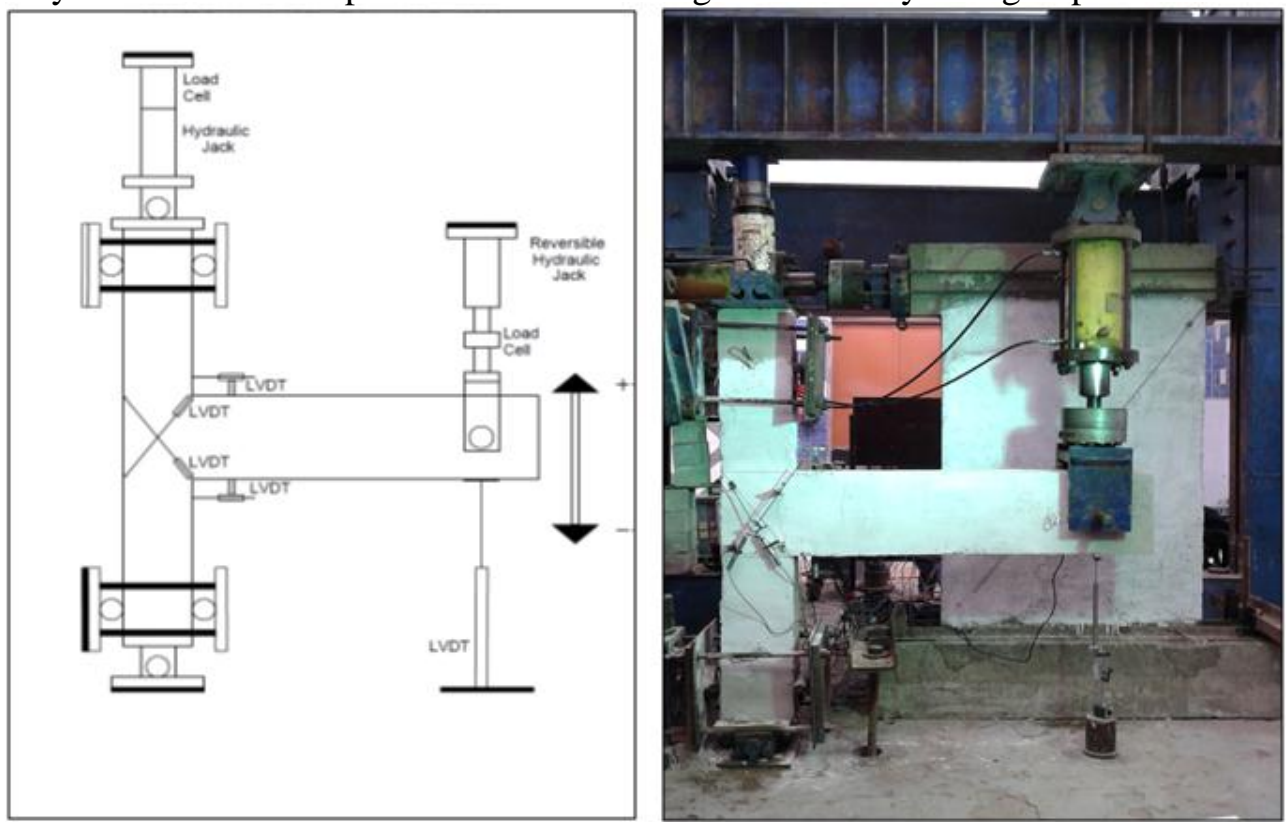

Fig. 2. Test arrangements. 


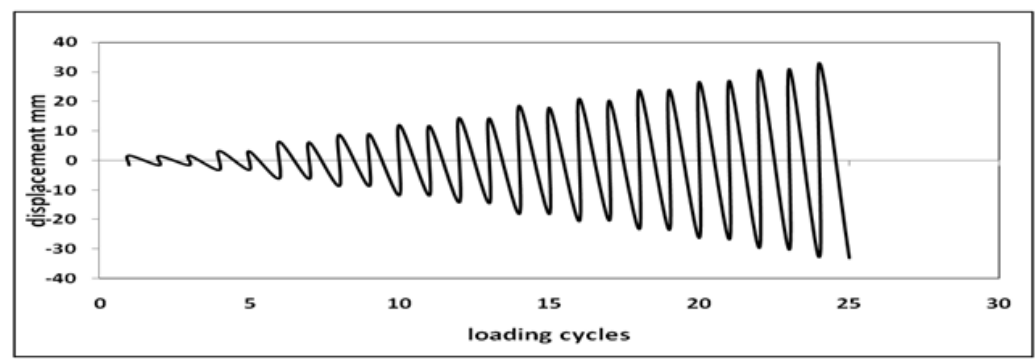

Fig. 3. Sequence of cyclic loading.

\section{Test results}

At the peak of each loading cycle, the cracking pattern was marked to help in obtaining information necessary for So that we can describe the failure mechanism of each test sample. All samples from the flexural cracks of poetry has suffered from the weak levels of displacement, In the cycles that followed these cracks spread along the beam to a distance measured from the column face and their widths increased The final failure of this joint was characterized by developing flexural plastic hinge over an average length measured from the beam-column interface

\subsection{Crack Pattern and Failure Mode}

The final crack patterns in different specimens are shown in Fig.4. In all specimens the first crack occurred from first loading cycle, then beam was loaded until the top steel bars of the beam were yielded in the loading cycle No (6, 5 and 3 ) for specimens R-CO,R-SP20 and R-SP15 respectively. The beam was loaded to reach the maximum load and the test continue up to strength degrade from $25 \%$ in this cycle the load reached to ultimate. Test was continuo up to failure was happened in loading cycle No23 for specimens R-CO, RSP20 and loading cycle No 25 for specimen R-SP15. After the end of the test and raising parts of collapsed concrete were measured distance at which cracks have spread in the body of the beam and found as follows $(900 \mathrm{~mm}, 750 \mathrm{~mm}$ and $800 \mathrm{~mm})$ for specimens R-CO , R-SP20 and R-SP15 respectively. Also observed the plastic hinge occurred the distance measured for column face $(150 \mathrm{~mm}, 152 \mathrm{~mm}$ and $128 \mathrm{~mm})$ for specimens R-CO, R-SP20 and R-SP15 respectively.

\subsection{Loads carrying capacity of specimens}

The values recorded loads and displacements attendant during the various stages of testing in Table No.3, beam capacity $=34 \mathrm{KN}$.R-CO sample reached to $87 \%$ and $60 \%$ from beam flexural failure loads for positive and negative loading direction respectively (average is $73.68 \%$ ) . However R-SP20 sample reached up to $97 \%$ and $71 \%$ from beam flexural failure loads for positive and negative loading direction respectively (average is $80.5 \%$ ) and R-SP15 reached up to $94 \%$ and $66 \%$ from beam flexural failure loads for positive and negative loading direction respectively (average is $84.26 \%$ ).[8]

This means that the lap splice has contributed to increasing the capacity of carrying loads a percentage ranging from $8 \%$ to $18 \%$ in positive and negative direction of loading and in average formula $6 \%$ for R-SP15and $10 \%$.for R-SP20. 
Girgis F.G. Sharobeem et al., Effect of using highly confined short lap-splice reinforcement on .......

\section{Table 3.}

loads carrying capacity and attendant displacements.

\begin{tabular}{|c|c|c|c|c|c|c|c|c|c|c|c|c|c|c|}
\hline \multirow{2}{*}{ sample } & \multicolumn{4}{|c|}{ Crack } & \multicolumn{2}{c|}{ Yield } & \multicolumn{4}{c|}{ Maximum } & \multicolumn{4}{c|}{ U1timate } \\
\cline { 2 - 16 } & Pcr & der & Pcr & der & Py & dy & Pmax & dmax & Pmax & dmax & Pu & du & Pu & du \\
\hline R-CO & 14.7 & 1.5 & -10.3 & -1.58 & -23.9 & -6.15 & 39.6 & 12.1 & -28.4 & -8.68 & 29.7 & 33.1 & -20.4 & -33.1 \\
\hline R-SP15 & 15.9 & 1.57 & -16.1 & -3.13 & -16.2 & -3.13 & 40.5 & 18.2 & -31.1 & -17.7 & 32.1 & 35.7 & -22.7 & -35.4 \\
\hline R-SP20 & 20.1 & 1.7 & -14.4 & -1.58 & -32.6 & -6.14 & 38.4 & 9.06 & -34.8 & -11.9 & 33 & 33.6 & -24.3 & -32.8 \\
\hline
\end{tabular}
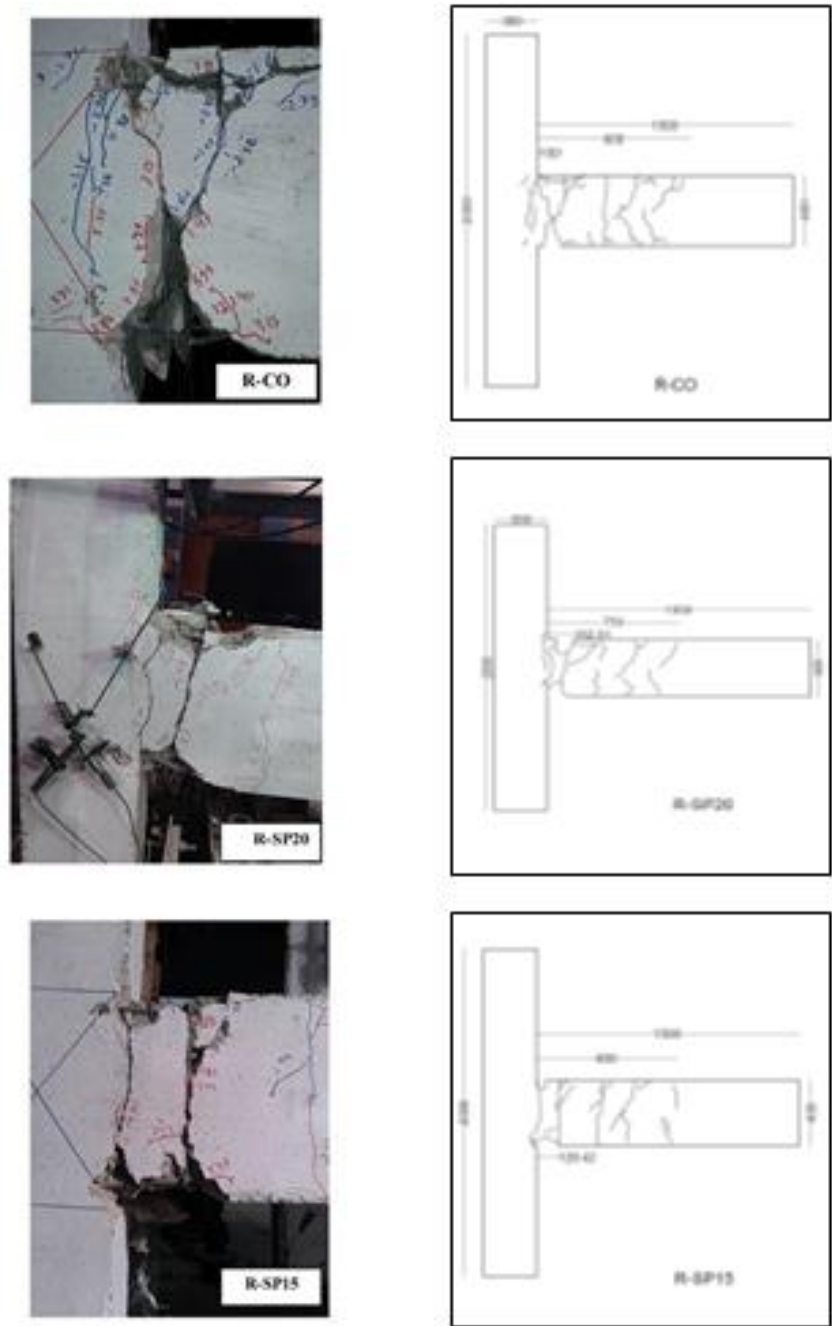

Fig. 4. Crack Patterns of test Specimen sat failure point

\subsection{Hysteretic loops}

The hysteretic loops of specimens are presented in the form of displacement versus corresponding applied load to beam shown in Figure from 5 to 7 , which have well been recognized as an effective qualitative means of evaluating the seismic performance. R-CO sample continued to resist loads until drift equal $(1.88 \%$ and $1.86 \%)$ for positive and 
negative direction of loading respectively then the sample began in the loss their stiffness and then collapse, while R-SP15 sample resist up to drift $(2.35 \%$ and $2.34 \%)$ for positive and negative direction of loading respectively and R-SP20 resist up to drift $(2.18 \%$ and $2.1 \%$ ) for positive and negative direction of loading respectively. From the curves observed that the joints reached to maximum drift at failure $(2.65 \%, 2.69 \%$ and $2.86 \%)$ for specimens (R-CO, R-SP20 and R-SP15) respectively.

This means that the lap splice has contributed to increasing drift a percentage ranging from $13 \%$ to $26 \%$ in positive and negative direction of loading before failure starting and at final has contributed to increasing drift up to $7.92 \%$ for R-SP15 and $1.5 \%$ for R-SP20

Figure 8and figure 9 show the average and envelop of loads and displacement relations.

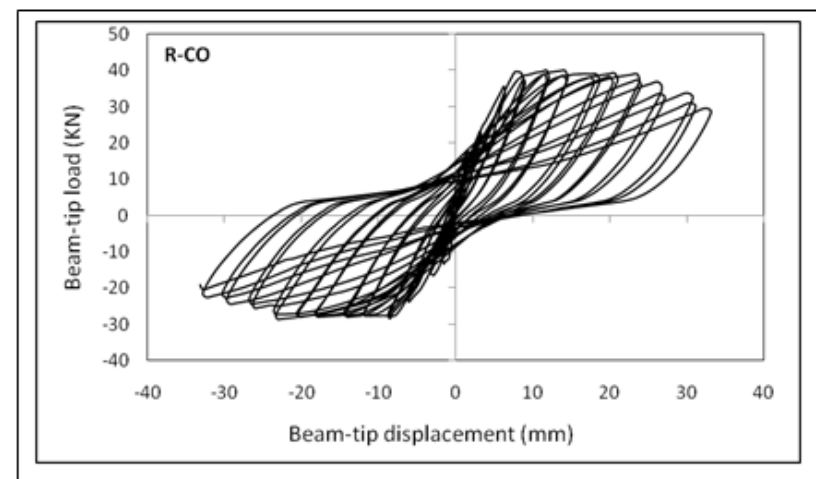

Fig. 5. Load-Displacement Hysteresis Loop for Specimen R-CO

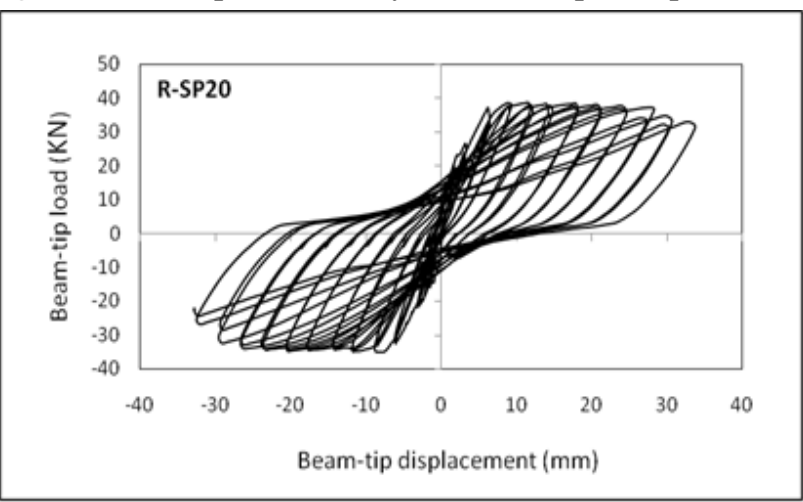

Fig. 6. Load-Displacement Hysteresis Loop for Specimen R-SP20

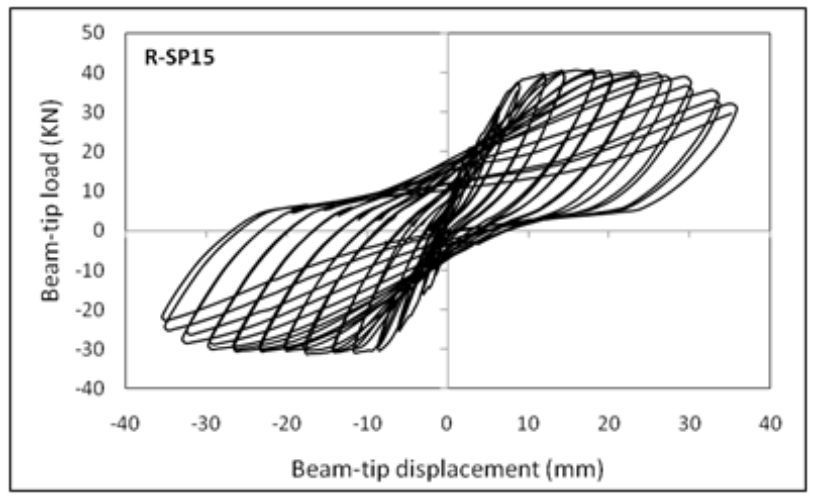

Fig. 7. Load-Displacement Hysteresis Loop for Specimen R-SP15 


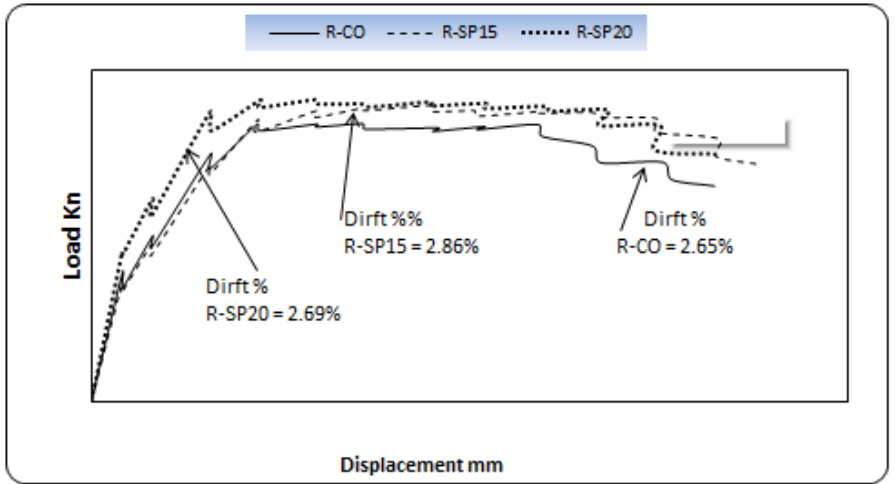

Fig. 8. average loads and displacements curves for test specimen.

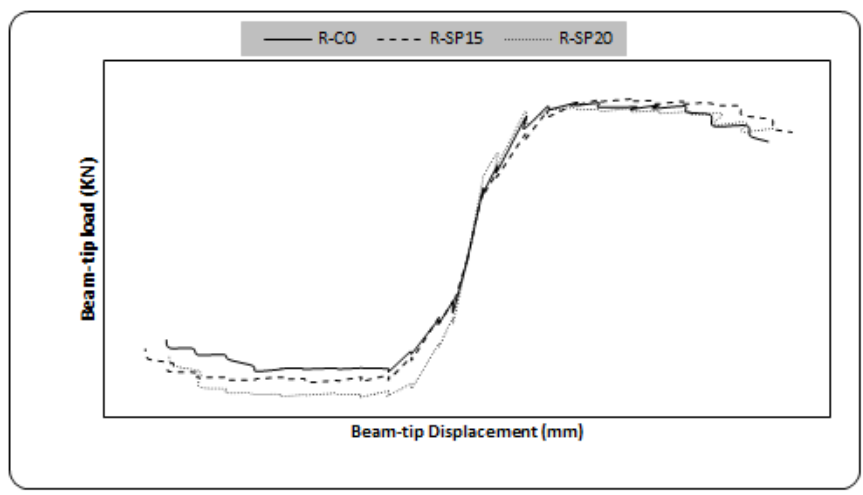

Fig. 9. Load-Displacement Envelope for test specimen.

\subsection{Displacement ductility factor}

It is necessary to have the beam column joint behavior in the earthquake-proof facilities will behave in ductile manner when exposed to earthquake loads. Ductility that are characteristic that allows the structure of which is subject to a large deformations after the initial deformation resulting from yield not loses its strength suddenly. [4] and [5]

The displacement ductility factor is the ratio of the maximum deformation that can element can undergo without significant loss of initial yield resistance to the initial yield deformation. Table 4 gives the experimental results of ductility factor, the values of the ductility factors indicate that the specimens (R-CO, R-SP15, and R-SP20) can be considered as ductile beam column joints.

Table 4.

Displacement Ductility of Test Specimens

\begin{tabular}{|c|c|c|c|c|c|}
\hline \multirow{2}{*}{ sample } & \multicolumn{4}{|c|}{ Displacement in mm } & Displacement \\
\cline { 2 - 5 } & \multirow{2}{*}{ Yield } & \multicolumn{3}{|c|}{$\begin{array}{c}\text { Ultimate } \\
\text { ductity factor } \\
\text { DDF }\end{array}$} \\
\cline { 2 - 5 } & & + direction & - direction & average & 5.39 \\
\hline R-CO & -6.15 & 33.13 & -33.12 & 33.13 & 11.37 \\
\hline R-SP15 & -3.13 & 35.74 & -35.43 & 35.59 & 5.41 \\
\hline R-SP20 & -6.14 & 33.64 & -32.79 & 33.22 & \\
\hline
\end{tabular}




\subsection{Energy dissipation capacity}

The structures are designed to be damaged not to be collapse when exposed to earthquakes. The earthquakes produce energy can be dissipated through the behavior of concrete elements that the concrete elements in the structure can resist earthquakes in case of dissipate of energy without resulting loss of strength. The energy dissipation is the area enclosed by the hysteretic loop; it is important factor in the seismic design and evaluation of the structure. When its value is reduced that means greater the level of damage.[6]

The cumulative energy dissipated for test specimens R-CO, R-SP20 and R-SP15 is (11286, 12975,15015 KN.mm) respectively. This means that the lap splice has contributed to increasing the energy dissipated a percentage ranging from $15 \%$ for R-SP20 and to 33\% for R-SP15.

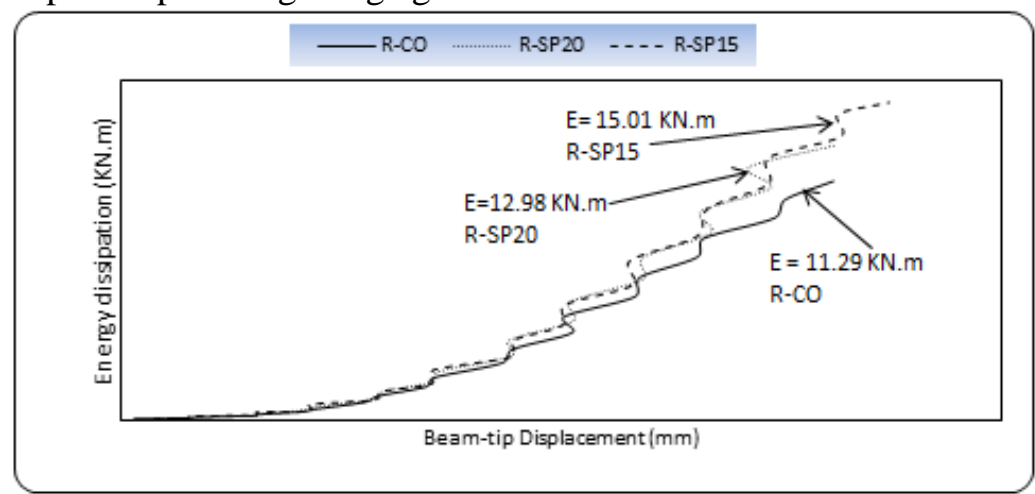

Fig. 10. cumulative energy dissipated for test specimens

\subsection{Stiffness}

Stiffness can calculate the approximate way, in each cycle load as follows: slope of the peak-to-peak line [7]. It was plotted the relationship between stiffness and its corresponding displacement at every cycle load as shown in Figure 11.It may be observed that the stiffness was $(13.6,15.13$ and $11.57 \mathrm{KN} / \mathrm{mm})$ for specimens R-CO, R-SP20 and RSP15 respectively. That means stiffness of R-SP20 increased by $11 \%$ from that of R-CO and as for R-SP15 stiffness decrease by $15 \%$ from that of R-CO.

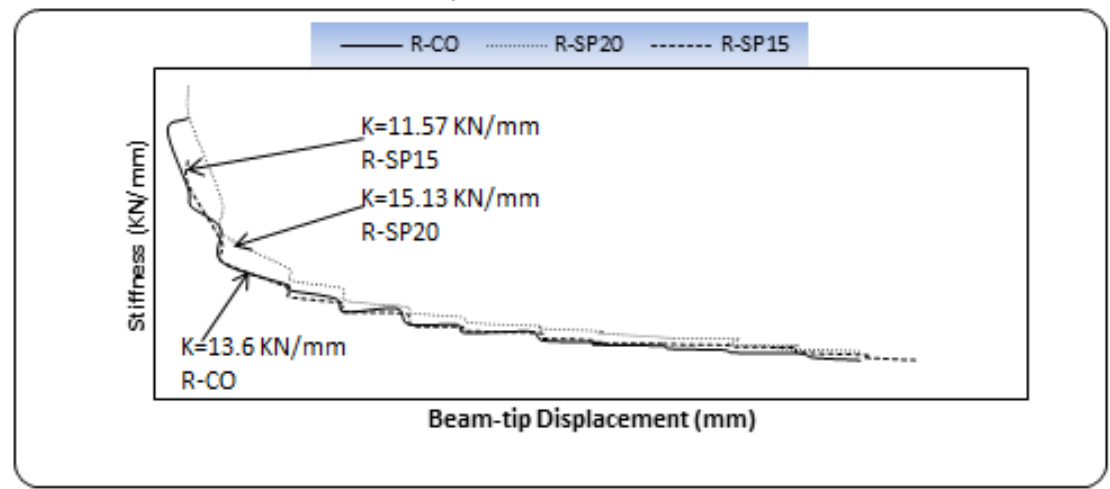

Fig. 11. Stiffness degradation for test specimens 


\section{Conclusions}

The purpose of this investigation was to evaluate the effect of using well confined short lap splice reinforcement on seismic performance of exterior beam column joint. Following conclusions have been drawn from this study:

All the specimens were cracked at the first cycle of loading, there is a convergence in the form of cracks and the spread of the beam and finally occurs of plastic hinge in beam then the failure was happen, failure in all joints is flexure failure mode and can be considered in all test specimens as a ductile beam column joints but the lap splice has played a clear role in the following:

- Development of steel yielding such as in cycle No (6,5 and 3) for specimens R-CO, R-SP20 and R-SP15 respectively.

Delayed the collapse of specimen such as cycle No23 for specimens R-CO, R-SP20 and loading cycle No 25 for specimen R-SP15.

- The lap splice has contributed to increasing the capacity of carrying loads a percentage ranging from $8 \%$ to $18 \%$ in positive and negative direction of loading and in average formula $6 \%$ for R-SP15 and $10 \%$.for R-SP20.

- The lap splice has contributed to increasing drift a percentage ranging from $13 \%$ to $26 \%$ in positive and negative direction of loading before failure starting and at final has contributed to increasing drift up to $7.92 \%$ for R-SP15 and $1.5 \%$ for R-SP20

- The lap splice has contributed to increasing the energy dissipated a percentage ranging from $15 \%$ for R-SP20 and to 33\% for R-SP15.

- The lap splice has contributed to increasing the stiffness of R-SP20 increased by $11 \%$ from that of R-CO and as for R-SP15 stiffness decrease by $15 \%$ from that of R-CO.

\section{REFERENCES}

[1] Aboutaha, R. S., Engelhardt, M. D., Jirsa, J. O., \& Kreger, M. E. (1996). Retrofit of concrete columns with inadequate lap splices by the use of rectangular steel jackets. Earthquake Spectra, 12(4), 693-714.

[2] Lynn, A. C., Moehle, J. P., Mahin, S. A., \& Holmes, W. T. (1996). Seismic evaluation of existing reinforced concrete building columns. Earthquake Spectra, 12(4), 715-739.

[3] Bahaa, T., "seismic behavior of reinforced high-strength concrete beam with and without steel fibers", Cairo university Egypt, February 2002.

[4] Paulay, T., \& Park, R. (1984). Joints in Reinforced Concrete Frames Designed for Earthquake Resistance: A Report Prepared for a US-New Zealand-Japan Seminar, 30 July-1 August 1984, Monterey, Calif. University of Canterbury.

[5] Park, R., \& Paulay, T. (1975). Reinforced concrete structures. John Wiley \& Sons.

[6] Elmenshawi, A., \& Brown, T. (2010). Hysteretic energy and damping capacity of flexural elements constructed with different concrete strengths. Engineering Structures, 32(1), 297-305.

[7] El-Amoury, T., \&Ghobarah, A. (2002). Seismic rehabilitation of beam column joint using GFRP sheets. Engineering Structures, 24(11), 1397-1407.

[8] Bindhu, K. R., \& Sreekumar, K. J. (2011). Seismic Resistance of Exterior Beam Column Joint with Diagonal Collar Stirrups. International Journal of Civil \& Structural Engineering, 2(1), 160-175. 


\section{تأثير استخدام وصلات قصيرة (التسليح الرئيسي للاعمدة ) و المقيدة جيدا علي سلوك وصله خارجيه لكمرة مع عمود تحت تأثير احمال الزلازل.}

الملخص:

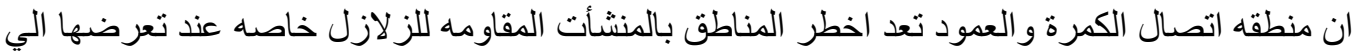

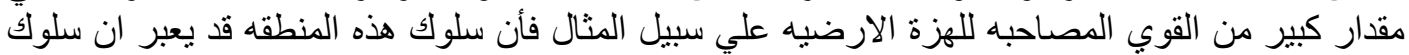
المنشأ بأكمله.

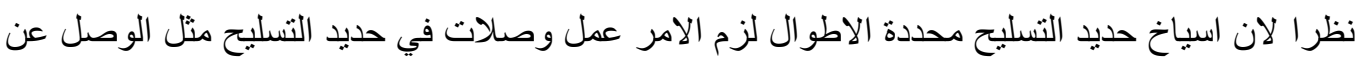

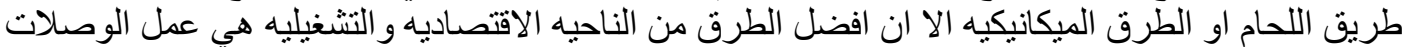

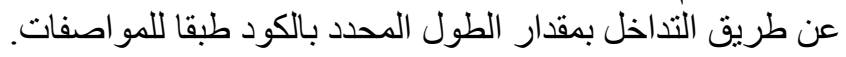

تهدف هذه الدراسه الي معرفه سلوك وصله خارجيه لكمرة مع عمود في حاله عمل تغير في التسليح

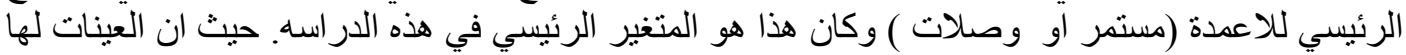

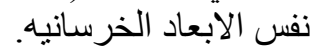

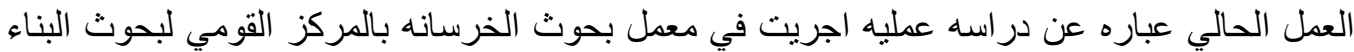

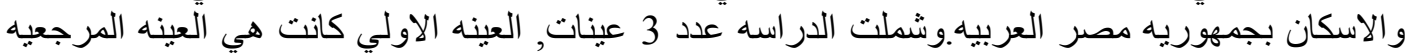

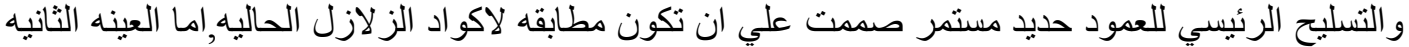
و الثالثه في حديد الاعمدة الرئيسي بهدوصنيد وصلات (15 مرة قطر السيخ و 20 مرة قطر السيخ ).

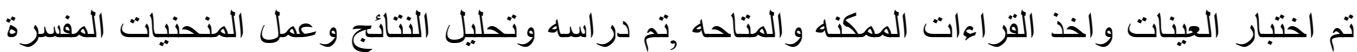
للنتائج ,وبعد ذللك تم عمل الاستنتاجات و التوصيات. الكلمات الداله: وصله ,كمرة مع عمود ,مقيدة ,وصله خارجيه رزلازل. 